\title{
Plitidepsin has potent preclinical efficacy against SARS-CoV-2 by targeting the host protein eEF1A
}

\author{
Kris M. White ${ }^{1,2 *+}$, Romel Rosales ${ }^{1,2 *}$, Soner Yildiz ${ }^{1,2}$, Thomas Kehrer,2, Lisa Miorin ${ }^{1,2}$, \\ Elena Moreno ${ }^{1,2}$, Sonia Jangra ${ }^{1,2}$, Melissa B. Uccellini ${ }^{1,2}$, Raveen Rathnasinghe ${ }^{1,2}$, Lynda Coughlan $^{3}$, \\ Carles Martinez-Romero ${ }^{1,2}$, Jyoti Batra ${ }^{4,5,6,7}$, Ajda Roj $\mathbf{~}^{4,5,6,7}$, Mehdi Bouhaddou ${ }^{4,5,6,7}$, \\ Jacqueline M. Fabius ${ }^{4,6}$, Kirsten Obernier ${ }^{4,5,6,7}$, Marion Dejosez $^{8}$, María José Guillén ${ }^{9}$, \\ Alejandro Losada ${ }^{9}$, Pablo Avilés ${ }^{9}$, Michael Schotsaert ${ }^{1,2}$, Thomas Zwaka $^{8}$, Marco Vignuzzi ${ }^{10}$,

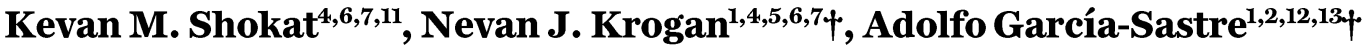

${ }^{1}$ Department of Microbiology, Icahn School of Medicine at Mount Sinai, New York, NY, USA. ${ }^{2}$ Global Health Emerging Pathogens Institute, Icahn School of Medicine at Mount Sinai, New York, NY, USA. ${ }^{3}$ Department of Microbiology and Immunology and Center for Vaccine Development and Global Health (CVD), University of Maryland School of Medicine, Baltimore, MD, USA. ${ }^{4}$ Quantitative Biosciences Institute (QBI), University of California, San Francisco, CA 94158, USA. ${ }^{5}$. David Gladstone Institutes, San Francisco, CA 94158, USA. ${ }^{6}$ QBI Coronavirus Research Group (QCRG), San Francisco, CA 94158, USA. ${ }^{7}$ Department of Cellular and Molecular Pharmacology, University of California, San Francisco, CA 94158, USA. ${ }^{8}$ Huffington Foundation Center for Cell-Based Research in Parkinson's Disease, Department for Cell, Regenerative and Developmental Biology, Black Family Stem Cell Institute, Icahn School of Medicine at Mount Sinai, New York, NY, USA. ${ }^{9}$ Research and Development Department, PharmaMar, 28770 Colmenar Viejo, Madrid, Spain. ${ }^{10}$ Viral Populations and Pathogenesis Unit, CNRS UMR 3569, Institut Pasteur, 75724 Paris Cedex 15, France. ${ }^{11}$ Howard Hughes Medical Institute, University of California, San Francisco, CA 94143, USA. ${ }^{12}$ Department of Medicine, Division of Infectious Diseases, Icahn School of Medicine at Mount Sinai, New York, NY, USA. ${ }^{13}$ Tisch Cancer Institute, Icahn School of Medicine at Mount Sinai, New York, NY, USA.

*These authors contributed equally to this work.

†Corresponding author. Email: kris.white@mssm.edu (K.M.W.); nevan.krogan@ucsf.edu (N.J.K.); adolfo.garcia-sastre@mssm.edu (A.G.-S.)

SARS-CoV-2 viral proteins interact with the eukaryotic translation machinery and inhibitors of translation have potent antiviral effects. Here we report that the drug plitidepsin (aplidin), which has limited clinical approval, possesses antiviral activity $\left(\mathrm{IC}_{90}=0.88 \mathrm{nM}\right) 27.5$-fold more potent than remdesivir against SARSCoV-2 in vitro, with limited toxicity in cell culture. Through the use of a drug resistant mutant, we show that the antiviral activity of plitidepsin against SARS-CoV-2 is mediated through inhibition of the known target eEF1A. We demonstrate the in vivo efficacy of plitidepsin treatment in two mouse models of SARSCoV-2 infection with a reduction of viral replication in the lungs by two orders of magnitude using prophylactic treatment. Our results indicate that plitidepsin is a promising therapeutic candidate for COVID-19.

Over the last 20 years, three novel coronaviruses $(\mathrm{CoV})$ have been introduced into the human population causing significant morbidity and mortality. The Severe Acute Respiratory Syndrome coronavirus (SARS-CoV) and Middle East Respiratory Syndrome coronavirus (MERS-CoV) epidemics were each limited in scope, but both are associated with severe disease and high mortality rates (1-3). The ongoing COVID19 pandemic caused by the SARS-CoV-2 virus, is the result of a zoonotic transmission event, similar to previous coronavirus epidemics (4-7). Recent studies have detected many SARS-like and MERS-like coronaviruses in natural bat reservoirs and shown them to be capable of replication in human lung cells in vitro (8-10). This suggests the presence of a large reservoir of coronaviruses with pandemic potential. Antiviral therapeutics are urgently needed to combat SARS-
CoV-2 in the current pandemic and will be the first line of defense for the future coronavirus epidemics that appear more likely as the human population expands in close contact with animal reservoirs.

COVID-19 is a viral-induced inflammatory disease of the airways and lungs with multi-organ involvement that can cause severe respiratory and systemic issues. SARS-CoV-2 replication in the lungs leads to inflammatory, innate and adaptive immune responses that cause significant host tissue damage $(3,11)$. COVID-19 can lead to end-stage lung disease and systemic involvement that currently has limited treatment options and poor prognoses. The current standards of care include oxygen therapy and ventilation, along with the antiviral remdesivir and the anti-inflammatory dexamethasone. Remdesivir $(12,13)$ and dexamethasone (14) 
have each improved patient outcomes in clinical trials and have been approved for emergency use by regulatory agencies, but remdesivir in particular has shown limited efficacy (15) and dexamethasone is a steroid that does not directly inhibit viral replication. This leaves a continued need for the development or repurposing of antiviral drugs for the treatment of COVID-19.

Our previously published SARS-CoV-2 (16) and pancoronaviral (17) interactomes highlighted 332 host proteins that are likely to play a role in the viral life cycle of SARSCoV-2. In that work we tested 47 existing drugs that were known to modulate these identified host proteins, with many of these drugs showing significant antiviral activity against SARS-CoV-2 in cell culture (16). Of the inhibitors tested, those that targeted the eukaryotic translation machinery (eIF4H interacts with SARS-CoV-2 Nsp9) demonstrated particularly potent antiviral activities. Zotatafin (18), an inhibitor of eIF4A (a partner of eIF4H), had a $90 \%$ inhibitory concentration $\left(\mathrm{IC}_{90}\right.$ ) of $154 \mathrm{nM}$ and ternatin-4 (19), an inhibitor of eEF1A which has potential interactions with multiple coronavirus proteins (17), had an $\mathrm{IC}_{90}$ of $15 \mathrm{nM}$ against SARS-CoV-2 in Vero E6 cells (16).

In an effort to further explore the therapeutic potential of host eEF1A as a target for the treatment of COVID-19, we evaluated the eEF1A inhibitor plitidepsin (aplidin), which has limited clinical approval for the treatment of multiple myeloma. Plitidepsin has also successfully completed a phase I/II clinical study for the treatment of COVID-19 (20, 21 ) by the pharmaceutical company PharmaMar and is moving forward into a Phase II/III COVID-19 study. We first tested plitidepsin inhibition of SARS-CoV-2 replication using an immunofluorescence-based antiviral screening assay in Vero E6 cells (22). Plitidepsin inhibited SARS-CoV-2 with an $\mathrm{IC}_{90}$ of $1.76 \mathrm{nM}$ (Fig. 1B), which was 9-fold more potent than ternatin- 4 and 87.5-fold more potent than zotatafin in the same assay (16). We next tested plitidepsin in the same antiviral assay using a human cell line (hACE2-293T). The anti-SARS-CoV-2 activity of plitidepsin was even more potent in human cells, with an $\mathrm{IC}_{90}$ of $0.88 \mathrm{nM}$ (Fig. 1D), which is 27.5 -fold more potent then remdesivir tested in the same cell line (Fig. 1C). The cytotoxicity of plitidepsin was examined in parallel with antiviral activity; at all concentrations, in both cell types, we observed a cytostatic impact on cell proliferation (Fig. 1, B and D). We have previously found the lack of a dose response curve in our cytotoxic assay to be suggestive of a cytostatic, rather than cytotoxic, effect on cells, but further work is required to confirm this hypothesis. Finally we tested the antiviral effect of plitidepsin in an established model of human pneumocyte-like cells $(23,24)$. We found that treatment with plitidepsin inhibited SARSCoV-2 replication (Fig. $1 \mathrm{E}$ ) with an $\mathrm{IC}_{90}$ of $3.14 \mathrm{nM}$ and a selectivity index of 40.4, suggesting that plitidepsin has po- tent antiviral activity in primary human lung cells.

In an effort to better understand the mechanism of action through which plitidepsin inhibits SARS-CoV-2 infection, we performed a time-of-addition assay in which plitidepsin or remdesivir was added to hACE2-293T cells at $-2,0,+2$, or +4 hours relative to infection. In this 8 hour single-cycle infection, we found that $20 \mathrm{nM}$ plitidepsin strongly inhibited NP-expression even when added 4 hours after infection (Fig. IF). This is indicative of a cytoplasmic replication stage inhibitor, which is consistent with the predicted antiviral mechanism of a known translation inhibitor.

Remdesivir is part of the current standard of care for the treatment of COVID-19 $(25,26)$. We therefore assessed the dynamics between the antiviral effects of plitidepsin and remdesivir when used together in vitro. Our analysis using the Synergyfinder (27) software suggests that plitidepsin has an additive effect with remdesivir (fig. S2) and would be a potential candidate to be considered in a combined therapy by having an additive effect with the current standard of care.

Plitidepsin inhibits the activity of the host factor eEF1A and is predicted to interact with the same binding site as didemnin $\mathrm{B}$, which is structurally related to plitidepsin, and the structurally unrelated ternatin-4. Exogenous overexpression of a A399V mutant of eEF1A confers resistance in cancer cells to both didemnin B (28) and ternatin-4 (29) inhibition and we predicted that it may similarly impact plitidepsin. We examined whether this A399V mutation could mitigate the observed anti-SARS-CoV-2 activity of plitidepsin. First, we transiently co-transfected $293 \mathrm{~T}$ cells with expression plasmids for hACE2 and either eEF1A-WT or eEF1A-A399V, which were confirmed to be expressed in approximately $30 \%$ of cells via immunofluorescent staining for the Flag epitope (fig. S1). We then measured the antiviral activity of plitidepsin against SARS-CoV-2 in these transfected 293T cells. Transfection with eEF1A-A399V, but not eEF1A-WT, increased the $\mathrm{IC}_{90}$ of plitidepsin by greater than 10-fold (Fig. 2A). Interestingly, no impact from the A399V mutant transfection was observed on plitidepsin inhibition of cell proliferation (Fig. 2D), consistent with observations of ternatin-4 (29). The differential effect of eEF1A-A399V transient transfection between the antiviral and antiproliferative impact of plitidepsin is consistent with previous findings that coronaviruses are significantly more sensitive to translation perturbations than the host cell $(30,31)$. We then generated an eEF1A-A399V CRISPR knock-in 293T cell line (293T-A399V) to further evaluate the role of eEF1A inhibition in the antiviral activity of plitidepsin. We found that this 293T-A399V cell line was refractory (greater than 12-fold) to the SARS-CoV-2 antiviral activity of plitidepsin as compared to the parental cell line (Fig. 2B), while not simi- 
larly impacting remdesivir inhibition (Fig. 2C). Furthermore, we found that plitidepsin antiviral activity could be almost fully restored through transient transfection of the 293T-A399V cells with wild type, but not mutant, eEF1A (Fig. 2B). This 293T-A399V cell line was also resistant to the anti-proliferative activity of plitidepsin and this could only be partially rescued by transfection of the wild type protein (Fig. 2E), again similar to previous results with ternatin-4 (29). Furthermore siRNA silencing of eEF1A protein expression during SARS-CoV-2 infection lead to a large reduction in viral $\mathrm{N}$ protein levels while not similarly impacting the GAPDH control (Fig. 2F). Taken together, this evidence indicates that the antiviral activity of plitidepsin is mediated through eEF1A inhibition and confirms eEF1A as a druggable target for the inhibition of SARS-CoV-2 replication.

We next explored the impact of plitidepsin treatment on viral RNA and protein production over the course of SARSCoV-2 infection. We analyzed the SARS-CoV-2 genomic and $\mathrm{N}$ sub-genomic RNA content of Vero E6 cells infected with SARS-CoV-2 at an MOI of 1 at 4, 8, 12, and 24 hours post infection in the presence or absence of equivalent inhibitory doses of plitidepsin or remdesivir. We found that plitidepsin significantly reduced genomic RNA content at 8 and 12 hours post infection and fell just short of significance at the 24 hour time point, similar to remdesivir treatment (Fig. 3A). Interestingly, plitidepsin had a much greater impact on the accumulation of the $\mathrm{N}$ sub-genomic RNA. Plitidepsin greatly reduced the sub-genomic RNA expression as early as 4 hours post infection and maintained a significant impact throughout the time course (Fig. 3B). Remdesivir had no effect on $\mathrm{N}$ sub-genomic RNA at 4 hours, but did show a reduction at all other time points tested. We then measured the viral $\mathrm{N}$ protein levels in the presence and absence of plitidepsin or remdesivir treatment. Similar to RNA levels, plitidepsin had a more potent and sustained inhibition of the expression the $\mathrm{N}$ protein over the time course of infection compared to remdesivir (Fig. 3, C and D). This specific inhibition of $\mathrm{N}$ sub-genomic RNA expression, particularly early in infection, is likely a result of the inhibition of viral translation by plitidepsin. It has been shown previously that coronaviruses are highly sensitive to translation inhibitors $(30,31)$ and that negative sense genome accumulation is more greatly impacted than the positive sense (32). The current model of coronavirus discontinuous transcription (33) has been guided by evidence that sub-genomic RNA formation occurs during negative strand synthesis (34). Therefore a translation inhibitor that more greatly impacts negative sense RNA production would also be expected to specifically reduce sub-genomic RNA formation and accumulation, as we observe with plitidepsin. Furthermore, consistent with an impact of plitidepsin in protein translation, $\mathrm{N}$ protein levels were more greatly reduced in plitidepsin treated cells compared to remdesivir at 24 hours post infection, when levels of N RNA were equivalent between these two treatments.

Plitidepsin has been clinically developed for the treatment of multiple myeloma with a well-established safety profile and pharmacokinetics (35-38). Initially, plitidepsin underwent a large clinical development program in which, cancer patients were treated with plitidepsin as a single agent in several phase I and II clinical trials. Results gathered from these clinical studies demonstrated that the probability of having cardiac adverse events, a concern in COVID-19 patients, was not significantly impacted by plitidepsin treatment (39-41), although these events were found in other chemically related compounds which display a different mechanism of action $(42,43)$. It is worth highlighting that plitidepsin had a good safety profile in a Phase I clinical trial (44), which administered a total of $11.4 \mathrm{mg}$ spaced over 5 days of treatment. The dose level used in the COVID19 proof of concept phase I study (21) had a maximum total of $7.5 \mathrm{mg}$ spaced over 3 days.

Based on this clinical safety data and good pharmacokinetics (fig. S3A) we determined that a concentration of plitidepsin an order of magnitude greater than the demonstrated in vitro $\mathrm{IC}_{90}$ could be safely achieved in the lungs of mice using a single daily dose. Therefore, we tested the in vivo efficacy of plitidepsin in two different established animal models of SARS-CoV-2 infection. First we used a human ACE2 expressing adenovirus to transduce the naturally resistant wild type BALB/c mice and sensitize them to SARS-CoV-2 infection (Fig. 4A) (45). Five days post adenovirus transduction, mice were infected with $1 \times 10^{4}$ pfu of SARS-CoV-2. As a proof-of-principle experiment, we performed prophylactic dosing with $0.3 \mathrm{mg} / \mathrm{kg}$ or $1 \mathrm{mg} / \mathrm{kg}$ plitidepsin 2 hours prior to infection with SARS-CoV-2. The 0.3 $\mathrm{mg} / \mathrm{kg}$ group received continued dosing once per day for 2 more days, while the $1 \mathrm{mg} / \mathrm{kg}$ group received only that single dose (Fig. 4B). SARS-CoV-2 lung titers were quantified from two independent experiments for the plitidepsin groups and compared to vehicle and remdesivir controls (Fig. 4C). There was nearly a 2 log reduction in SARS-CoV-2 viral titers in the lungs of the $0.3 \mathrm{mg} / \mathrm{kg}$ plitidepsin group compared to the vehicle control group, while there was a 1.5 $\log$ reduction observed from the single dose of $1 \mathrm{mg} / \mathrm{kg}$ plitidepsin. It should be noted that we used a very high concentration of remdesivir in these assays $(50 \mathrm{mg} / \mathrm{kg}$ ) because of the known high concentration of esterases present in mouse serum that degrade remdesivir (46).

We then performed a study in the K18-hACE2 mouse model (Fig. 5A), which supports a robust SARS-CoV-2 infection $(45,47)$, in which the $0.3 \mathrm{mg} / \mathrm{kg}$ dosage of plitidepsin was assessed for ability to reduce viral titers and inflammation in the lung. K18-hACE2 mice were treated with one dai- 
ly dose of plitidepsin for 3 days starting 2 hours before infection with SARS-CoV-2 (Fig. 5B). We found a 2 log reduction in viral lung titers at day 3 , similar to two daily 50 $\mathrm{mg} / \mathrm{kg}$ doses of remdesivir (Fig. 5C). Histopathology analysis (Fig. 5D) also showed a reduction a lung inflammation in plitidepsin treated mice (histopathology score of $1 / 16$ ) over vehicle treated (histopathology score of 5.4/16) and remdesivir treated (histopathology score of 2.3/16) mice at day 3 post infection (Fig. 5E). There was no peribronchiolar inflammation noted in the plitidepsin treated group. Taken together these experiments show that plitidepsin treatment can reduce the replication of SARS-CoV-2 by 2 orders of magnitude and reduce lung inflammation in vivo and has significant potential for clinical efficacy for the treatment of COVID-19.

The ongoing SARS-CoV-2 pandemic has created the immediate need for antiviral therapeutics that can be moved into the clinic within months rather than years. This led us to screen clinically-approved drugs with established bioavailability, pharmacokinetics and safety profiles. Our previous study of the SARS-CoV-2 interactome (16) led us to eEF1A as a druggable target with the potential for potent inhibition of SARS-CoV-2 in vitro. eEF1A has been previously described to be an important host factor for the replication of many viral pathogens (48-50), including influenza virus (51) and RSV (52). Specifically, it has been found to be involved in transmissible gastroenteritis coronavirus (TGEV) replication (53) and was detected in SARS-CoV virions (54). Therefore, inhibition of eEF1A as a strategy for the treatment of viral infection may extend to other human coronaviruses and beyond to unrelated viral pathogens. This potential for broad-spectrum antiviral activity makes plitidepsin an intriguing candidate for further exploration as a treatment for viral infections with no clinically approved therapeutics. It is also important to note that a hosttargeted antiviral such as plitidepsin offers protection from naturally occurring viral mutants, such as the variant recently discovered in the United Kingdom $(55,56)$, to which viral-targeted therapeutics and vaccines are more susceptible.

In our animal experiments, we did detect a slight body weight loss of mice that were treated with plitidepsin daily, while mice that received a single $1 \mathrm{mg} / \mathrm{kg}$ dose did not lose any weight while still exhibiting reductions in viral lung titers (fig. S3B). It is unclear whether this observed toxicity is mouse-specific and while toxicity is a concern with any host-targeted antiviral, the safety profile of plitidepsin is well established in humans. Furthermore, the dose of plitidepsin being used in an ongoing COVID-19 clinical trial is significantly less than used in these experiments and it has been well tolerated in patients with minimal side effects. Interestingly, the most well established and effective steroid for the treatment of COVID-19, dexamethasone (14), is also a commonly used treatment for multiple myeloma (57). This has led to plitidepsin already having an established safety profile with concurrent dexamethasone treatment $(58,59)$ and should allow for clinicians to treat with both drugs if warranted. This study establishes plitidepsin as a hosttargeted anti-SARS-CoV-2 agent with in vivo efficacy. We believe that our data and the initial positive results from PharmaMar's clinical trial suggests that plitidepsin should be strongly considered for expanded clinical trials for the treatment of COVID-19.

\section{REFERENCES AND NOTES}

1. World Health Organization, "Middle East respiratory syndrome coronavirus (MERS-COV)"; www.who.int/emergencies/mers-cov/en/.

2. E. de Wit, N. van Doremalen, D. Falzarano, V. J. Munster, SARS and MERS: Recent insights into emerging coronaviruses. Nat. Rev. Microbiol. 14, 523-534 (2016). doi:10.1038/nrmicro.2016.81 Medline

3. D. Wang, B. Hu, C. Hu, F. Zhu, X. Liu, J. Zhang, B. Wang, H. Xiang, Z. Cheng, Y. Xiong, Y. Zhao, Y. Li, X. Wang, Z. Peng, Clinical Characteristics of 138 Hospitalized Patients With 2019 Novel Coronavirus-Infected Pneumonia in Wuhan, China. JAMA 323, 1061-1069 (2020). doi:10.1001/jama.2020.1585 Medline

4. Y. Z. Zhang, E. C. Holmes, A Genomic Perspective on the Origin and Emergence of SARS-CoV-2. Cell 181, 223-227 (2020). doi:10.1016/i.cell.2020.03.035 Medline

5. K. G. Andersen, A. Rambaut, W. I. Lipkin, E. C. Holmes, R. F. Garry, The proximal origin of SARS-CoV-2. Nat. Med. 26, 450-452 (2020). doi:10.1038/s41591-0200820-9 Medline

6. B. Hu, X. Ge, L. F. Wang, Z. Shi, Bat origin of human coronaviruses. Virol. J. 12, 221 (2015). doi:10.1186/s12985-015-0422-1 Medline

7. S. J. Anthony, K. Gilardi, V. D. Menachery, T. Goldstein, B. Ssebide, R. Mbabazi, I. Navarrete-Macias, E. Liang, H. Wells, A. Hicks, A. Petrosov, D. K. Byarugaba, K. Debbink, K. H. Dinnon, T. Scobey, S. H. Randell, B. L. Yount, M. Cranfield, C. K. Johnson, R. S. Baric, W. I. Lipkin, J. A. K. Mazet, Further Evidence for Bats as the Evolutionary Source of Middle East Respiratory Syndrome Coronavirus. mBio 8, e00373-17 (2017). doi:10.1128/mBio.00373-17 Medline

8. V. D. Menachery, B. L. Yount Jr., A. C. Sims, K. Debbink, S. S. Agnihothram, L. E. Gralinski, R. L. Graham, T. Scobey, J. A. Plante, S. R. Royal, J. Swanstrom, T. P. Sheahan, R. J. Pickles, D. Corti, S. H. Randell, A. Lanzavecchia, W. A. Marasco, R. S. Baric, SARS-like WIV1-CoV poised for human emergence. Proc. Natl. Acad. Sci. U.S.A. 113, 3048-3053 (2016). doi:10.1073/pnas.1517719113 Medline

9. V. D. Menachery, B. L. Yount Jr., K. Debbink, S. Agnihothram, L. E. Gralinski, J. A. Plante, R. L. Graham, T. Scobey, X.-Y. Ge, E. F. Donaldson, S. H. Randell, A. Lanzavecchia, W. A. Marasco, Z.-L. Shi, R. S. Baric, A SARS-like cluster of circulating bat coronaviruses shows potential for human emergence. Nat. Med. 21, 1508-1513 (2015). doi:10.1038/nm.3985 Medline

10. P. C. Woo, S. K. P. Lau, K. S. M. Li, R. W. S. Poon, B. H. L. Wong, H. W. Tsoi, B. C. K. Yip, Y. Huang, K. H. Chan, K. Y. Yuen, Molecular diversity of coronaviruses in bats. Virology 351, 180-187 (2006). doi:10.1016/j.virol.2006.02.041 Medline

11. Y. Liang, M.-L. Wang, C.-S. Chien, A. A. Yarmishyn, Y.-P. Yang, W.-Y. Lai, Y.-H. Luo, Y.-T. Lin, Y.-J. Chen, P.-C. Chang, S.-H. Chiou, Highlight of Immune Pathogenic Response and Hematopathologic Effect in SARS-CoV, MERS-CoV, and SARSCov-2 Infection. Front. Immunol. 11, 1022 (2020). doi:10.3389/fimmu.2020.01022 Medline

12. C. D. Spinner, R. L. Gottlieb, G. J. Criner, J. R. Arribas López, A. M. Cattelan, A. Soriano Viladomiu, O. Ogbuagu, P. Malhotra, K. M. Mullane, A. Castagna, L. Y. A. Chai, M. Roestenberg, O. T. Y. Tsang, E. Bernasconi, P. Le Turnier, S.-C. Chang, D. SenGupta, R. H. Hyland, A. O. Osinusi, H. Cao, C. Blair, H. Wang, A. Gaggar, D. 
M. Brainard, M. J. McPhail, S. Bhagani, M. Y. Ahn, A. J. Sanyal, G. Huhn, F. M. Marty, Effect of Remdesivir vs Standard Care on Clinical Status at 11 Days in Patients With Moderate COVID-19: A Randomized Clinical Trial. JAMA 324, 1048-1057 (2020). doi:10.1001/iama.2020.16349 Medline

13. Y. Wang, D. Zhang, G. Du, R. Du, J. Zhao, Y. Jin, S. Fu, L. Gao, Z. Cheng, Q. Lu, Y. Hu, G. Luo, K. Wang, Y. Lu, H. Li, S. Wang, S. Ruan, C. Yang, C. Mei, Y. Wang, D. Ding, F. Wu, X. Tang, X. Ye, Y. Ye, B. Liu, J. Yang, W. Yin, A. Wang, G. Fan, F. Zhou, Z. Liu, X. Gu, J. Xu, L. Shang, Y. Zhang, L. Cao, T. Guo, Y. Wan, H. Qin, Y. Jiang, T. Jaki, F. G. Hayden, P. W. Horby, B. Cao, C. Wang, Remdesivir in adults with severe COVID-19: A randomised, double-blind, placebo-controlled, multicentre trial. Lancet 395, 1569-1578 (2020). doi:10.1016/S0140-6736(20)31022-9 Medline

14. RECOVERY Collaborative Group, Dexamethasone in Hospitalized Patients with Covid-19-Preliminary Report. N. Engl. J. Med. NEJMoa2021436 (2020). doi:10.1056/NEJMoa2021436

15. WHO Solidarity Trial Consortium, Repurposed Antiviral Drugs for COVID-19Interim WHO SOLIDARITY Trial Results. N. Engl. J. Med. NEJMoa2023184 (2020). doi:10.1056/NEJMoa2023184

16. D. E. Gordon, G. M. Jang, M. Bouhaddou, J. Xu, K. Obernier, K. M. White, M. J. O'Meara, V. V. Rezelj, J. Z. Guo, D. L. Swaney, T. A. Tummino, R. Hüttenhain, R. M. Kaake, A. L. Richards, B. Tutuncuoglu, H. Foussard, J. Batra, K. Haas, M. Modak, M. Kim, P. Haas, B. J. Polacco, H. Braberg, J. M. Fabius, M. Eckhardt, M. Soucheray, M. J. Bennett, M. Cakir, M. J. McGregor, Q. Li, B. Meyer, F. Roesch, T. Vallet, A. Mac Kain, L. Miorin, E. Moreno, Z. Z. C. Naing, Y. Zhou, S. Peng, Y. Shi, Z. Zhang, W. Shen, I. T. Kirby, J. E. Melnyk, J. S. Chorba, K. Lou, S. A. Dai, I. Barrio-Hernandez, D. Memon, C. Hernandez-Armenta, J. Lyu, C. J. P. Mathy, T. Perica, K. B. Pilla, S. J. Ganesan, D. J. Saltzberg, R. Rakesh, X. Liu, S. B. Rosenthal, L. Calviello, S. Venkataramanan, J. Liboy-Lugo, Y. Lin, X.-P. Huang, Y. Liu, S. A. Wankowicz, M. Bohn, M. Safari, F. S. Ugur, C. Koh, N. S. Savar, Q. D. Tran, D. Shengjuler, S. J. Fletcher, M. C. O'Neal, Y. Cai, J. C. J. Chang, D. J. Broadhurst, S. Klippsten, P. P. Sharp, N. A. Wenzell, D. Kuzuoglu-Ozturk, H.-Y. Wang, R. Trenker, J. M. Young, D. A. Cavero, J. Hiatt, T. L. Roth, U. Rathore, A. Subramanian, J. Noack, M. Hubert, R. M. Stroud, A. D. Frankel, O. S. Rosenberg, K. A. Verba, D. A. Agard, M. Ott, M. Emerman, N. Jura, M. von Zastrow, E. Verdin, A. Ashworth, O. Schwartz, C. d'Enfert, S. Mukherjee, M. Jacobson, H. S. Malik, D. G. Fujimori, T. Ideker, C. S. Craik, S. N. Floor, J. S. Fraser, J. D. Gross, A. Sali, B. L. Roth, D. Ruggero, J. Taunton, T. Kortemme, P. Beltrao, M. Vignuzzi, A. GarcíaSastre, K. M. Shokat, B. K. Shoichet, N. J. Krogan, A SARS-CoV-2 protein interaction map reveals targets for drug repurposing. Nature 583, 459-468 (2020). doi:10.1038/s41586-020-2286-9 Medline

17. D. E. Gordon, J. Hiatt, M. Bouhaddou, V. V. Rezelj, S. Ulferts, H. Braberg, A. S. Jureka, K. Obernier, J. Z. Guo, J. Batra, R. M. Kaake, A. R. Weckstein, T. W. Owens, M. Gupta, S. Pourmal, E. W. Titus, M. Cakir, M. Soucheray, M. McGregor, Z. Cakir, G. Jang, M. J. O'Meara, T. A. Tummino, Z. Zhang, H. Foussard, A. Rojc, Y. Zhou, D. Kuchenov, R. Hüttenhain, J. Xu, M. Eckhardt, D. L. Swaney, J. M. Fabius, M. Ummadi, B. Tutuncuoglu, U. Rathore, M. Modak, P. Haas, K. M. Haas, Z. Z. C. Naing, E. H. Pulido, Y. Shi, I. Barrio-Hernandez, D. Memon, E. Petsalaki, A. Dunham, M. C. Marrero, D. Burke, C. Koh, T. Vallet, J. A. Silvas, C. M. Azumaya, C. Billesbølle, A. F. Brilot, M. G. Campbell, A. Diallo, M. S. Dickinson, D. Diwanji, N. Herrera, N. Hoppe, H. T. Kratochvil, Y. Liu, G. E. Merz, M. Moritz, H. C. Nguyen, C. Nowotny, C. Puchades, A. N. Rizo, U. Schulze-Gahmen, A. M. Smith, M. Sun, I. D. Young, J. Zhao, D. Asarnow, J. Biel, A. Bowen, J. R. Braxton, J. Chen, C. M. Chio, U. S. Chio, I. Deshpande, L. Doan, B. Faust, S. Flores, M. Jin, K. Kim, V. L. Lam, F. Li, J. Li, Y.-L. Li, Y. Li, X. Liu, M. Lo, K. E. Lopez, A. A. Melo, F. R. Moss 3rd, P. Nguyen, J. Paulino, K. I. Pawar, J. K. Peters, T. H. Pospiech Jr., M. Safari, S. Sangwan, K. Schaefer, P. V. Thomas, A. C. Thwin, R. Trenker, E. Tse, T. K. M. Tsui, F. Wang, N. Whitis, Z. Yu, K. Zhang, Y. Zhang, F. Zhou, D. Saltzberg, A. J. Hodder, A. S. Shun-Shion, D. M. Williams, K. M. White, R. Rosales, T. Kehrer, L. Miorin, E. Moreno, A. H. Patel, S. Rihn, M. M. Khalid, A. Vallejo-Gracia, P. Fozouni, C. R. Simoneau, T. L. Roth, D. Wu, M. A. Karim, M. Ghoussaini, I. Dunham, F. Berardi, S. Weigang, M. Chazal, J. Park, J. Logue, M. McGrath, S. Weston, R. Haupt, C. J. Hastie, M. Elliott, F. Brown, K. A. Burness, E. Reid, M. Dorward, C. Johnson, S. G. Wilkinson, A. Geyer, D. M. Giesel, C. Baillie, S. Raggett, H. Leech, R. Toth, N. Goodman, K. C. Keough, A. L. Lind, R. J. Klesh, K. R. Hemphill, J.
Carlson-Stevermer, J. Oki, K. Holden, T. Maures, K. S. Pollard, A. Sali, D. A. Agard, Y. Cheng, J. S. Fraser, A. Frost, N. Jura, T. Kortemme, A. Manglik, D. R. Southworth, R. M. Stroud, D. R. Alessi, P. Davies, M. B. Frieman, T. Ideker, C. Abate, N. Jouvenet, G. Kochs, B. Shoichet, M. Ott, M. Palmarini, K. M. Shokat, A. García-Sastre, J. A. Rassen, R. Grosse, O. S. Rosenberg, K. A. Verba, C. F. Basler, M. Vignuzzi, A. A. Peden, P. Beltrao, N. J. Krogan, QCRG Structural Biology Consortium, Zoonomia Consortium, Comparative host-coronavirus protein interaction networks reveal pan-viral disease mechanisms. Science 370 , eabe9403 (2020). doi:10.1126/science abe9403 Medline

18. J. T. Ernst, P. A. Thompson, C. Nilewski, P. A. Sprengeler, S. Sperry, G. Packard, T. Michels, A. Xiang, C. Tran, C. J. Wegerski, B. Eam, N. P. Young, S. Fish, J. Chen, H. Howard, J. Staunton, J. Molter, J. Clarine, A. Nevarez, G. G. Chiang, J. R. Appleman, K. R. Webster, S. H. Reich, Design of Development Candidate eFT226, a First in Class Inhibitor of Eukaryotic Initiation Factor 4A RNA Helicase. J. Med. Chem. 63, 5879-5955 (2020). doi:10.1021/acs.jmedchem.0c00182 Medline

19. M. Ito, J. Ito, H. Kitazawa, K. Shimamura, T. Fukami, S. Tokita, K. Shimokawa, K. Yamada, A. Kanatani, D. Uemura, (-)-Ternatin inhibits adipogenesis and lipid metabolism in 3T3-L1 cells. Peptides 30, 1074-1081 (2009). doi:10.1016/j.peptides.2009.02.008 Medline

20. Spanish Clinical Trials Registry, 2020-001993-31: reec.aemps.es/reec/estudio/2020-001993-31.

21. ClinicalTrials.gov, NCT04382066: https://clinicaltrials.gov/ct2/show/NCT04382066?term=plitidepsin\&draw=2\& rank=8.

22. F. Amanat, K. M. White, L. Miorin, S. Strohmeier, M. McMahon, P. Meade, W.-C. Liu, R. A. Albrecht, V. Simon, L. Martinez-Sobrido, T. Moran, A. García-Sastre, F. Krammer, An In Vitro Microneutralization Assay for SARS-CoV-2 Serology and Drug Screening. Curr. Protoc. Microbiol. 58, e108 (2020). doi:10.1002/cpmc.108 Medline

23. A. Jacob, M. Vedaie, D. A. Roberts, D. C. Thomas, C. Villacorta-Martin, K.-D. Alysandratos, F. Hawkins, D. N. Kotton, Derivation of self-renewing lung alveolar epithelial type II cells from human pluripotent stem cells. Nat. Protoc. 14, 33033332 (2019). doi:10.1038/s41596-019-0220-0 Medline

24. M. Ghaedi, E. A. Calle, J. J. Mendez, A. L. Gard, J. Balestrini, A. Booth, P. F. Bove, L. Gui, E. S. White, L. E. Niklason, Human iPS cell-derived alveolar epithelium repopulates lung extracellular matrix. J. Clin. Invest. 123, 4950-4962 (2013). doi:10.1172/JC168793 Medline

25. R. A. Siemieniuk, J. J. Bartoszko, L. Ge, D. Zeraatkar, A. Izcovich, E. Kum, H. Pardo-Hernandez, B. Rochwerg, F. Lamontagne, M. A. Han, Q. Liu, A. Agarwal, T. Agoritsas, D. K. Chu, R. Couban, A. Darzi, T. Devji, B. Fang, C. Fang, S. A. Flottorp, F. Foroutan, M. Ghadimi, D. Heels-Ansdell, K. Honarmand, L. Hou, X. Hou, Q. Ibrahim, A. Khamis, B. Lam, M. Loeb, M. Marcucci, S. L. McLeod, S. Motaghi, S. Murthy, R. A. Mustafa, J. D. Neary, A. Qasim, G. Rada, I. B. Riaz, B. Sadeghirad, N. Sekercioglu, L. Sheng, A. Sreekanta, C. Switzer, B. Tendal, L. Thabane, G. Tomlinson, T. Turner, P. O. Vandvik, R. W. M. Vernooij, A. Viteri-García, Y. Wang, L. Yao, Z. Ye, G. H. Guyatt, R. Brignardello-Petersen, Drug treatments for covid19: Living systematic review and network meta-analysis. BMJ 370, m2980 (2020). doi:10.1136/bmi.m2980 Medline

26. Y. Yokoyama, A. Briasoulis, H. Takagi, T. Kuno, Effect of remdesivir on patients with COVID-19: A network meta-analysis of randomized control trials. Virus Res, 288, 198137 (2020). doi:10.1016/i.virusres.2020.198137 Medline

27. A. lanevski, A. K. Giri, T. Aittokallio, SynergyFinder 2.0: Visual analytics of multidrug combination synergies. Nucleic Acids Res. 48, W488-W493 (2020). doi:10.1093/nar/gkaa216 Medline

28. P. Krastel, S. Roggo, M. Schirle, N. T. Ross, F. Perruccio, P. Aspesi Jr., T. Aust, K. Buntin, D. Estoppey, B. Liechty, F. Mapa, K. Memmert, H. Miller, X. Pan, R. Riedl, C. Thibaut, J. Thomas, T. Wagner, E. Weber, X. Xie, E. K. Schmitt, D. Hoepfner, Nannocystin A: An Elongation Factor 1 Inhibitor from Myxobacteria with Differential Anti-Cancer Properties. Angew. Chem. Int. Ed. 54, 10149-10154 (2015). doi:10.1002/anie.201505069 Medline

29. J. D. Carelli, S. G. Sethofer, G. A. Smith, H. R. Miller, J. L. Simard, W. C. Merrick, R. 
K. Jain, N. T. Ross, J. Taunton, Ternatin and improved synthetic variants kill cancer cells by targeting the elongation factor-1A ternary complex. eLife 4 , e10222 (2015). doi:10.7554/el ife.10222 Medline

30. S. H. van den Worm, K. Knoops, J. C. Zevenhoven-Dobbe, C. Beugeling, Y. van der Meer, A. M. Mommaas, E. J. Snijder, Development and RNA-synthesizing activity of coronavirus replication structures in the absence of protein synthesis. J. Virol. 85, 5669-5673 (2011). doi:10.1128/JVL.00403-11 Medline

31. D. Bojkova, K. Klann, B. Koch, M. Widera, D. Krause, S. Ciesek, J. Cinatl, C. Münch, Proteomics of SARS-CoV-2-infected host cells reveals therapy targets. Nature 583, 469-472 (2020). doi:10.1038/s41586-020-2332-7 Medline

32. S. G. Sawicki, D. L. Sawicki, Coronavirus minus-strand RNA synthesis and effect of cycloheximide on coronavirus RNA synthesis. J. Virol. 57, 328-334 (1986) doi:10.1128/JVI.57.1.328-334.1986 Medline

33. S. G. Sawicki, D. L. Sawicki, S. G. Siddell, A contemporary view of coronavirus transcription. J. Virol. 81, 20-29 (2007). doi:10.1128/JVl.01358-06 Medline

34. S. G. Sawicki, D. L. Sawicki, Coronaviruses use discontinuous extension for synthesis of subgenome-length negative strands. Adv. Exp. Med. Biol. 380, 499506 (1995). doi:10.1007/978-1-4615-1899-0_79 Medline

35. J. Delgado-Calle, N. Kurihara, E. G. Atkinson, J. Nelson, K. Miyagawa, C. M. Galmarini, G. D. Roodman, T. Bellido, Aplidin (plitidepsin) is a novel antimyeloma agent with potent anti-resorptive activity mediated by direct effects on osteoclasts. Oncotarget 10, 2709-2721 (2019). doi:10.18632/oncotarget.26831 Medline

36. L. Yao, Aplidin PharmaMar. IDrugs 6, 246-250 (2003). Medline

37. P. E. Morande, S. R. Zanetti, M. Borge, P. Nannini, C. Jancic, R. F. Bezares, A. Bitsmans, M. González, A. L. Rodríguez, C. M. Galmarini, R. Gamberale, M. Giordano, The cytotoxic activity of Aplidin in chronic lymphocytic leukemia (CLL) is mediated by a direct effect on leukemic cells and an indirect effect on monocyte-derived cells. Invest. New Drugs 30, 1830-1840 (2012). doi:10.1007/s10637-011-9740-3 Medline

38. C. S. Mitsiades, E. M. Ocio, A. Pandiella, P. Maiso, C. Gajate, M. Garayoa, D. Vilanova, J. C. Montero, N. Mitsiades, C. J. McMullan, N. C. Munshi, T. Hideshima, D. Chauhan, P. Aviles, G. Otero, G. Faircloth, M. V. Mateos, P. G. Richardson, F. Mollinedo, J. F. San-Miguel, K. C. Anderson, Aplidin, a marine organism-derived compound with potent antimyeloma activity in vitro and in vivo. Cancer Res. 68 , 5216-5225 (2008). doi:10.1158/0008-5472.CAN-07-5725 Medline

39. R. Nalda-Molina, B. Valenzuela, A. Ramon-Lopez, B. Miguel-Lillo, A. Soto-Matos, J. J. Perez-Ruixo, Population pharmacokinetics meta-analysis of plitidepsin (Aplidin) in cancer subjects. Cancer Chemother. Pharmacol. 64, 97-108 (2009). doi:10.1007/s00280-008-0841-4 Medline

40. A. Soto-Matos, S. Szyldergemajn, S. Extremera, B. Miguel-Lillo, V. Alfaro, C. Coronado, P. Lardelli, E. Roy, C. S. Corrado, C. Kahatt, Plitidepsin has a safe cardiac profile: A comprehensive analysis. Mar. Drugs 9, 1007-1023 (2011). do: $10.3390 / \mathrm{md} 9061007$ Medline

41. R. Salazar, R. Plummer, A. Oaknin, A. Robinson, B. Pardo, A. Soto-Matos, A. Yovine, S. Szyldergemajn, A. H. Calvert, Phase I study of weekly plitidepsin as 1hour infusion combined with carboplatin in patients with advanced solid tumors or lymphomas. Invest. New Drugs 29, 1406-1413 (2011). doi:10.1007/s10637010-9488-1 Medline

42. R. L. Piekarz, A. R. Frye, J. J. Wright, S. M. Steinberg, D. J. Liewehr, D. R. Rosing, V. Sachdev, T. Fojo, S. E. Bates, Cardiac studies in patients treated with depsipeptide, FK228, in a phase II trial for T-cell lymphoma. Clin. Cancer Res. 12, 3762-3773 (2006). doi:10.1158/1078-0432.CCR-05-2095 Medline

43. M. H. Shah, P. Binkley, K. Chan, J. Xiao, D. Arbogast, M. Collamore, Y. Farra, D. Young, M. Grever, Cardiotoxicity of histone deacetylase inhibitor depsipeptide in patients with metastatic neuroendocrine tumors. Clin. Cancer Res. 12, 39974003 (2006). doi:10.1158/1078-0432.CCR-05-2689 Medline

44. J. A. Maroun, K. Belanger, L. Seymour, S. Matthews, J. Roach, J. Dionne, D. Soulieres, D. Stewart, R. Goel, D. Charpentier, G. Goss, E. Tomiak, J. Yau, J. Jimeno, G. Chiritescu, Phase I study of Aplidine in a daily $\times 5$ one-hour infusion every 3 weeks in patients with solid tumors refractory to standard therapy. A
National Cancer Institute of Canada Clinical Trials Group study: NCIC CTG IND 115. Ann. Oncol. 17, 1371-1378 (2006). doi:10.1093/annonc/mdl165 Medline

45. R. Rathnasinghe, S. Strohmeier, F. Amanat, V. L. Gillespie, F. Krammer, A. GarcíaSastre, L. Coughlan, M. Schotsaert, M. Uccellini, Comparison of Transgenic and Adenovirus hACE2 Mouse Models for SARS-CoV-2 Infection. Emerg. Microbes Infect. 9, 2433-2445 (2020). doi:10.1080/22221751.2020.1838955

46. T. P. Sheahan, A. C. Sims, R. L. Graham, V. D. Menachery, L. E. Gralinski, J. B. Case, S. R. Leist, K. Pyrc, J. Y. Feng, I. Trantcheva, R. Bannister, Y. Park, D. Babusis, M. O. Clarke, R. L. Mackman, J. E. Spahn, C. A. Palmiotti, D. Siegel, A. S. Ray, T. Cihlar, R. Jordan, M. R. Denison, R. S. Baric, Broad-spectrum antiviral GS5734 inhibits both epidemic and zoonotic coronaviruses. Sci. Transl. Med. 9 , eaal3653 (2017). doi:10.1126/scitranslmed.aal3653 Medline

47. E. S. Winkler, A. L. Bailey, N. M. Kafai, S. Nair, B. T. McCune, J. Yu, J. M. Fox, R. E. Chen, J. T. Earnest, S. P. Keeler, J. H. Ritter, L. I. Kang, S. Dort, A. Robichaud, R. Head, M. J. Holtzman, M. S. Diamond, SARS-CoV-2 infection of human ACE2transgenic mice causes severe lung inflammation and impaired function. Nat. Immunol. 21, 1327-1335 (2020). doi:10.1038/s41590-020-0778-2 Medline

48. D. Li, T. Wei, C. M. Abbott, D. Harrich, The unexpected roles of eukaryotic translation elongation factors in RNA virus replication and pathogenesis. Microbiol. Mol. Biol. Rev. 77, 253-266 (2013). doi:10.1128/MMBR.00059-12 Medline

49. W. Abbas, A. Kumar, G. Herbein, The eEF1A Proteins: At the Crossroads of Oncogenesis, Apoptosis, and Viral Infections. Front. Oncol. 5, 75 (2015). doi:10.3389/fonc. 2015.00075 Medline

50. N. S. Heaton, N. Moshkina, R. Fenouil, T. J. Gardner, S. Aguirre, P. S. Shah, N. Zhao, L. Manganaro, J. F. Hultquist, J. Noel, D. Sachs, J. Hamilton, P. E. Leon, A. Chawdury, S. Tripathi, C. Melegari, L. Campisi, R. Hai, G. Metreveli, A. V. Gamarnik, A. García-Sastre, B. Greenbaum, V. Simon, A. Fernandez-Sesma, N. J. Krogan, L. C. F. Mulder, H. van Bakel, D. Tortorella, J. Taunton, P. Palese, I. Marazzi, Targeting Viral Proteostasis Limits Influenza Virus, HIV, and Dengue Virus Infection. Immunity 44, 46-58 (2016). doi:10.1016/i.immuni.2015.12.017 Medline

51. S. Sammaibashi, S. Yamayoshi, Y. Kawaoka, Strain-Specific Contribution of Eukaryotic Elongation Factor 1 Gamma to the Translation of Influenza A Virus Proteins. Front. Microbiol. 9, 1446 (2018). doi:10.3389/fmicb.2018.01446 Medline

52. T. Wei, D. Li, D. Marcial, M. Khan, M.-H. Lin, N. Snape, R. Ghildyal, D. Harrich, K. Spann, The eukaryotic elongation factor $1 A$ is critical for genome replication of the paramyxovirus respiratory syncytial virus. PLOS ONE 9, e114447 (2014). doi:10.1371/journal.pone.0114447 Medline

53. X. Zhang, H. Shi, J. Chen, D. Shi, C. Li, L. Feng, EF1A interacting with nucleocapsid protein of transmissible gastroenteritis coronavirus and plays a role in virus replication. Vet. Microbiol. 172, 443-448 (2014). doi:10.1016/i.vetmic.2014.05.034 Medline

54. B. W. Neuman, J. S. Joseph, K. S. Saikatendu, P. Serrano, A. Chatterjee, M. A. Johnson, L. Liao, J. P. Klaus, J. R. Yates 3rd, K. Wüthrich, R. C. Stevens, M. J. Buchmeier, P. Kuhn, Proteomics analysis unravels the functional repertoire of coronavirus nonstructural protein 3. J. Virol. 82, 5279-5294 (2008). doi:10.1128/JVI.02631-07 Medline

55. S. V. Rajkumar, Multiple myeloma: 2020 update on diagnosis, risk-stratification and management. Am. J. Hematol. 95, 548-567 (2020). doi:10.1002/aih.25791 Medline

56. New and Emerging Respiratory Virus Threats Advisory Group, NERVTAG meeting on SARS-CoV-2 variant under investigation VUI-202012/01 (18 December 2020); https://khub.net/documents/135939561/338928724/SARS-CoV2+variant+under+investigation\%2C+meeting+minutes.pdf/962e866b-161f2fd5-1030-32b6ab467896?t=1608491166921.

57. A. Rambautet al., Preliminary genomic characterisation of an emergent SARSCoV-2 lineage in the UK defined by a novel set of spike mutations (18 December 2020); https://virological.org/t/preliminary-genomic-characterisation-of-anemergent-sars-cov-2-lineage-in-the-uk-defined-by-a-novel-set-of-spike- 
mutations/563.

58. I. Spicka, E. M. Ocio, H. E. Oakervee, R. Greil, R. H. Banh, S.-Y. Huang, J. M. D'Rozario, M. A. Dimopoulos, S. Martínez, S. Extremera, C. Kahatt, V. Alfaro, A. M. Carella, N. Meuleman, R. Hájek, A. Symeonidis, C.-K. Min, P. Cannell, H. Ludwig, P. Sonneveld, M. V. Mateos, Randomized phase III study (ADMYRE) of plitidepsin in combination with dexamethasone vs. dexamethasone alone in patients with relapsed/refractory multiple myeloma. Ann. Hematol. 98, 21392150 (2019). doi:10.1007/s00277-019-03739-2 Medline

59. M. Leisch, A. Egle, R. Greil, Plitidepsin: A potential new treatment for relapsed/refractory multiple myeloma. Future Oncol. 15, 109-120 (2019). doi:10.2217/fon-2018-0492 Medline

60. T. C. Chou, Theoretical basis, experimental design, and computerized simulation of synergism and antagonism in drug combination studies. Pharmacol. Rev. 58, 621-681 (2006). doi:10.1124/pr.58.3.10 Medline

61. L. Riva, S. Yuan, X. Yin, L. Martin-Sancho, N. Matsunaga, L. Pache, S. BurgstallerMuehlbacher, P. D. De Jesus, P. Teriete, M. V. Hull, M. W. Chang, J. F.-W. Chan, J. Cao, V. K.-M. Poon, K. M. Herbert, K. Cheng, T. H. Nguyen, A. Rubanov, Y. Pu, C. Nguyen, A. Choi, R. Rathnasinghe, M. Schotsaert, L. Miorin, M. Dejosez, T. P. Zwaka, K.-Y. Sit, L. Martinez-Sobrido, W.-C. Liu, K. M. White, M. E. Chapman, E. K. Lendy, R. J. Glynne, R. Albrecht, E. Ruppin, A. D. Mesecar, J. R. Johnson, C. Benner, R. Sun, P. G. Schultz, A. I. Su, A. García-Sastre, A. K. Chatterjee, K.-Y. Yuen, S. K. Chanda, Discovery of SARS-CoV-2 antiviral drugs through large-scale compound repurposing. Nature 586, 113-119 (2020). doi:10.1038/s41586-0202577-1 Medline

62. L. Coughlan, A. C. Bradshaw, A. L. Parker, H. Robinson, K. White, J. Custers, J. Goudsmit, N. Van Roijen, D. H. Barouch, S. A. Nicklin, A. H. Baker, Ad5:Ad48 hexon hypervariable region substitutions lead to toxicity and increased inflammatory responses following intravenous delivery. Mol. Ther. 20, 22682281 (2012). doi:10.1038/mt.2012.162 Medline

63. L. Coughlan, S. Vallath, A. Saha, M. Flak, I. A. McNeish, G. Vassaux, J. F. Marshall, I. R. Hart, G. J. Thomas, In vivo retargeting of adenovirus type 5 to alphavbeta6 integrin results in reduced hepatotoxicity and improved tumor uptake following systemic delivery. J. Virol. 83, 6416-6428 (2009). doi:10.1128/JVI.00445-09 Medline

\section{ACKNOWLEDGMENTS}

We thank Randy Albrecht for support with the BSL3 facility and procedures at the ISMMS and Richard Cadagan for technical assistance. We would like to thank Jack Taunton for helpful insights and assistance in regards to eEF1A inhibitors. Funding: This research was partly funded by the Defense Advanced Research Projects Agency (HR0011-19-2-0020) to A.G-S., N.J.K., and K.M.S.; by CRIP (Center for Research for Influenza Pathogenesis), a NIAID supported Center of Excellence for Influenza Research and Surveillance (CEIRS, contract \# HHSN272201400008C); by supplements to NIAID grant U19AI135972 and DoD grant W81XWH-20-1-0270; by the generous support of the JPB Foundation and the Open Philanthropy Project (research grant 2020-215611 (5384); and by anonymous donors to A.G-S. This research was also funded by the Huffington Foundation to T.Z..; by the National Institutes of Health (P50Al150476, U19Al135990, U19Al135972, R01Al143292, R01Al120694, P01A1063302, and R01Al122747 to N.J.K.; 1R01CA221969 and 1R01CA244550 to K.M.S.; and F32CA239333 to M.B.); by the Excellence in Research Award (ERA) from the Laboratory for Genomics Research (LGR), a collaboration between UCSF, UCB, and GSK (grant number 133122P to N.J.K.); by the Laboratoire d'Excellence "Integrative Biology of Emerging Infectious Diseases" grant ANR-10LABX-62-IBEID (to M.V.); and by funding from FastGrants COVID19 grant from the Emergent Ventures program at the Mercatus Center of George Mason University, F. Hoffmann-La Roche, Vir Biotechnology, the Roddenberry Foundation, and gifts from QCRG philanthropic donors to N.J.K.. S.Y. received funding from Swiss National Foundation (SNF) Early Postdoc.Mobility fellowship (P2GEP3_184202). Author contributions: K.M.W., N.J.K, and A.G.S. conceived and co-directed the study; K.M.W., N.J.K., A.G.S., R.Ros., S.Y., L.C., M.B., P.A., T.Z., and K.M.S. designed the experiments; K.M.W, R.Ros, S.Y., T.K, L.M., E.M., S.J., J.B., A.R., and M.D. performed in vitro experiments; K.M.W, R.Ros, S.Y., M.B.U., R.Rath., C.M.R., M.J.G., A.L., P.A., and M.S. performed in vivo experiments; K.M.W, N.J.K, A.G.S, R.Ros., S.Y., M.B.,
J.M.F., K.O., M.J.G., A.L., P.A., M.V., and K.M.S. interpreted the data; and K.M.W, N.J.K, A.G.S, R.Ros., S.Y., S.J., M.B., M.D., P.A., and T.Z. wrote the manuscript. All authors read and accepted the manuscript. Competing interests: The García-Sastre Laboratory has received research support from Pfizer, Senhwa Biosciences and 7Hills Pharma. Adolfo García-Sastre has consulting agreements for the following companies involving cash and/or stock: Vivaldi Biosciences, Contrafect, 7Hills Pharma, Avimex, Vaxalto, Accurius and Esperovax. The Krogan Laboratory receives funding from Roche and VIR and Nevan Krogan has consulting agreements with Maze Therapeutics and Interline Therapeutics. Kevan Shokat has consulting agreements for the following companies involving cash and/or stock compensation: Black Diamond Therapeutics, BridGene Biosciences, Denali Therapeutics, Dice Molecules, eFFECTOR Therapeutics, Erasca, Genentech/Roche, Janssen Pharmaceuticals, Kumquat Biosciences, Kura Oncology, Merck, Mitokinin, Petra Pharma, Revolution Medicines, Type6 Therapeutics, Venthera, Wellspring Biosciences (Araxes Pharma), Turning Point Therapeutics, Ikena, Nextech. María José Guillén, Alejandro Losada, and Pablo Avilés are employees and shareholders of PharmaMar, SA (Madrid,

Spain). Data and materials availability: Plitidepsin is available from PharmaMar for non-commercial use under an MTA. All relevant data are included within this manuscript and all materials other than plitidepsin are readily available upon request from Kris White, Nevan Krogan, or Adolfo Garcia-Sastre. This work is licensed under a Creative Commons Attribution 4.0 International (CC BY 4.0) license, which permits unrestricted use, distribution, and reproduction in any medium, provided the original work is properly cited. To view a copy of this license, visit

https://creativecommons.org/licenses/by/4.0/. This license does not apply to figures/photos/artwork or other content included in the article that is credited to a third party; obtain authorization from the rights holder before using such material.

\section{SUPPLEMENTARY MATERIALS}

science.sciencemag.org/cgi/content/full/science.abf4058/DC1

Materials and Methods

Figs. S1 to S3

References (60-63)

MDAR Reproducibility Checklist

28 October 2020; accepted 20 January 2021

Published online 25 January 2021

10.1126/science.abf4058 
A

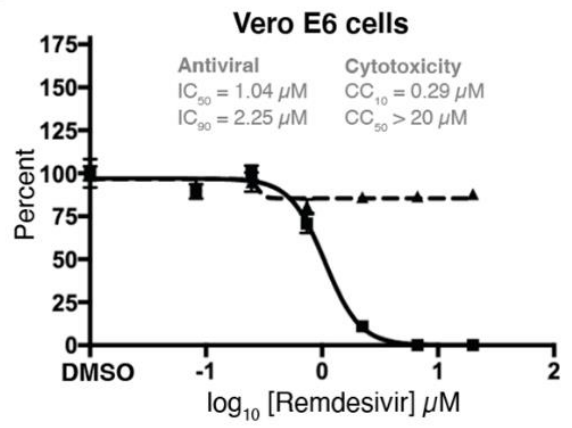

B

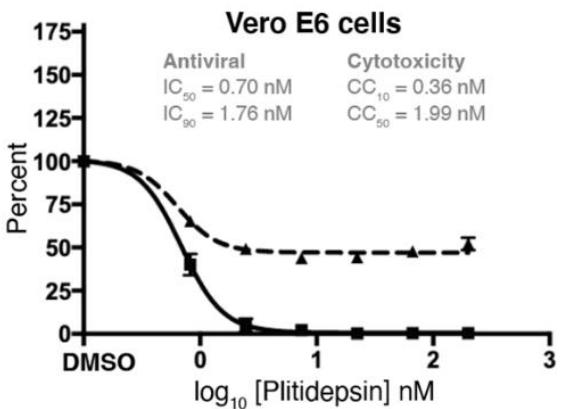

C
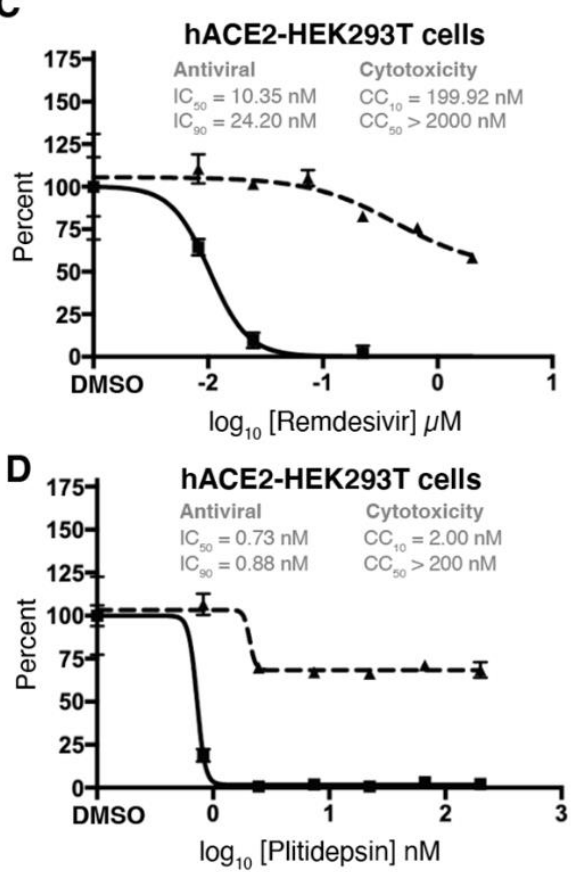

E

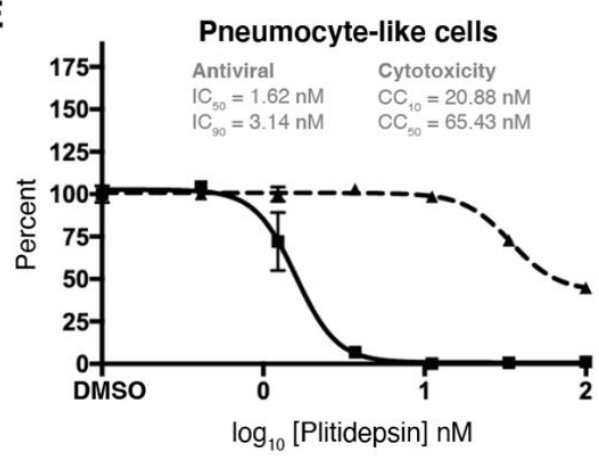

$\mathbf{F}$

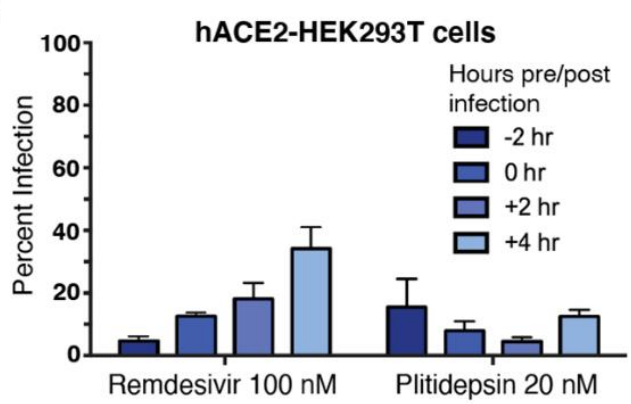

SARS-CoV-2 (anti-NP) - $\mathbf{A}-$ Cell viability

Fig. 1. Plitidepsin exhibits a strong antiviral activity in SARS-CoV-2 multiple cells lines. (A to E) Vero E6 cells [(A) and (B)], hACE2-293T cells [(C) and (D)], or pneumocyte-like cells (E) were treated with indicated doses of remdesivir [(A) and (C)] or plitidepsin [(B), (D), and (E)]. IC50, IC90, CC50 and CC10 values are indicated above the curves. All cells were pretreated for 2 hours and the drugs were maintained in the media throughout the experiment. SARS-CoV-2 infection and cell viability were measured at 48 hours. (F) The antiviral activity of plitidepsin and remdesivir was evaluated in pretreatment and post infection time points in hACE2-293T cells. Means \pm SD (error bars) of three independent experiments performed in biological triplicate are indicated. 
A

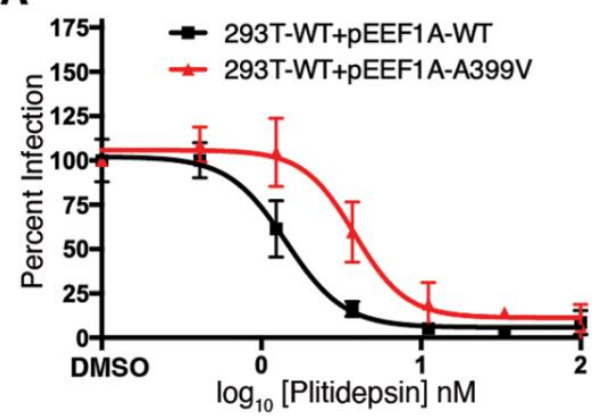

D

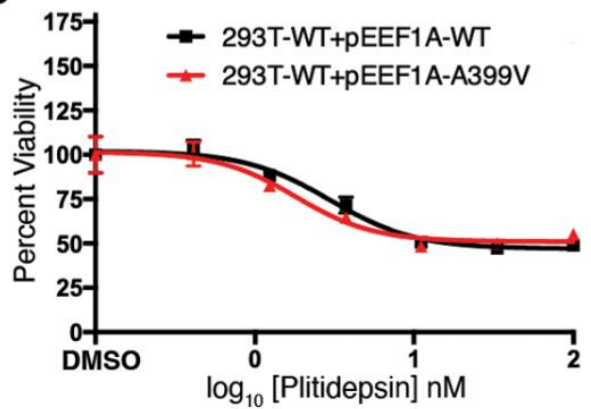

B

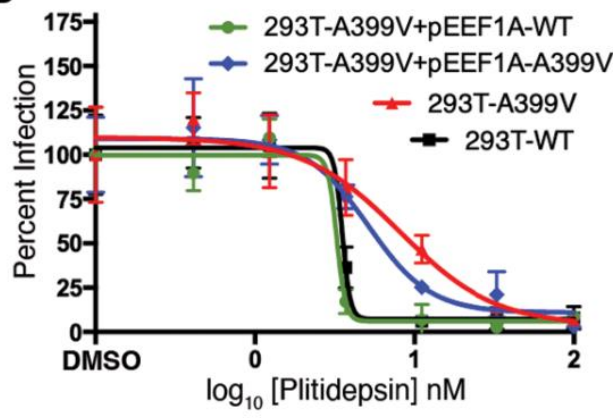

E

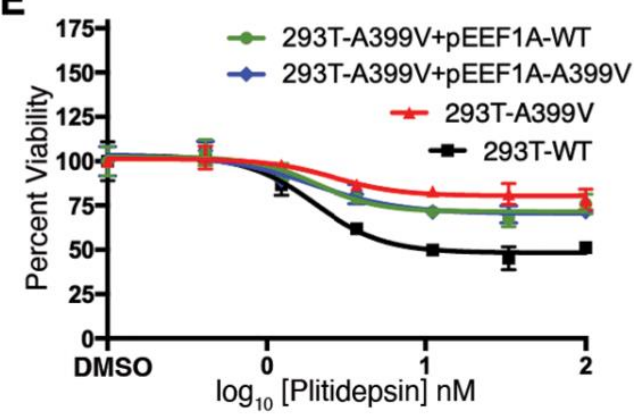

C

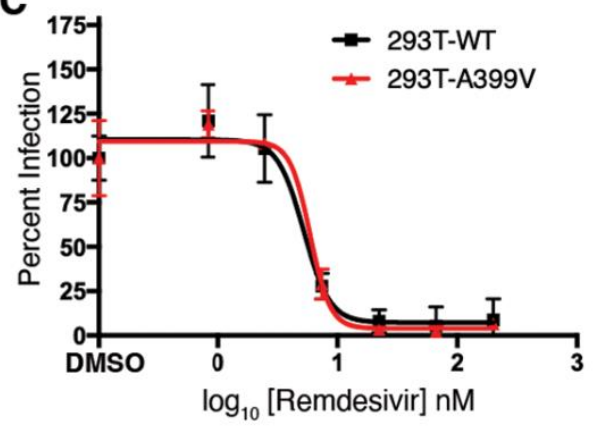

$\mathbf{F}$

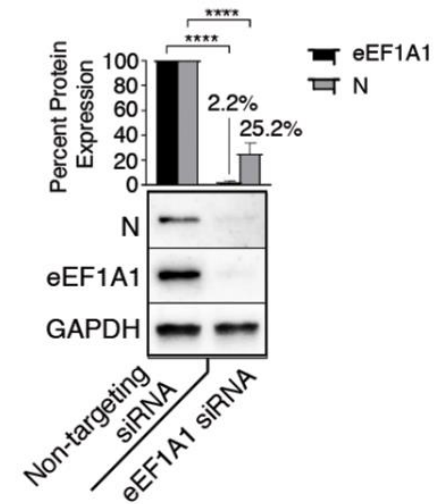

Fig. 2. Antiviral mechanism of action of plitidepsin is mediated through inhibition of eEF1A. (A) Plitidepsin inhibition of SARS-CoV-2 replication in 293T cells transfected with WT eEF1A, A399V mutant eEF1A, or the non-target eEF2A expression vectors. Plitidepsin inhibition is reduced by expression of the A399V mutation, while virus replication in wild type and eEF2A transfected mutations remain susceptible to treatment with plitidepsin. (B and C) Plitidepsin (B) and remdesivir (C) inhibition of SARS-CoV-2 replication in a CRISPR 293T cell line carrying a A399V mutation in eEF1A. Viral replication in eEF1A wild type preserve susceptibility to plitidepsin inhibition, while the presence of the eEF1A A399V mutation rendered the SARS-CoV-2 infection resistant to the eEF1A inhibitor. Remdesivir inhibition of SARS-CoV-2 viral replication is not affected by the A399V mutation. (D and E) Plitidepsin inhibition of cell proliferation as measured by MTT assay is not impacted by transfection of the A399V mutant (D), but is reduced by the 293T-A399V CRISPR cell line (E). (F) siRNA silencing of eEF1A greatly reduces $\mathrm{N}$ protein levels. Means $\pm \mathrm{SD}$ (error bars) of three independent experiments performed in biological triplicate are indicated $\left({ }^{*} P<0.05,{ }^{*} \mathrm{P}<0.01,{ }^{* *} \mathrm{P}<0.001\right.$, and $\left.{ }^{* * * *} \mathrm{P}<0.0001\right)$. 
A

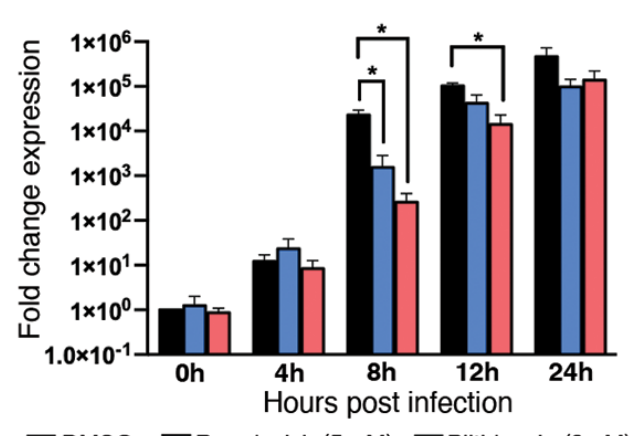

B

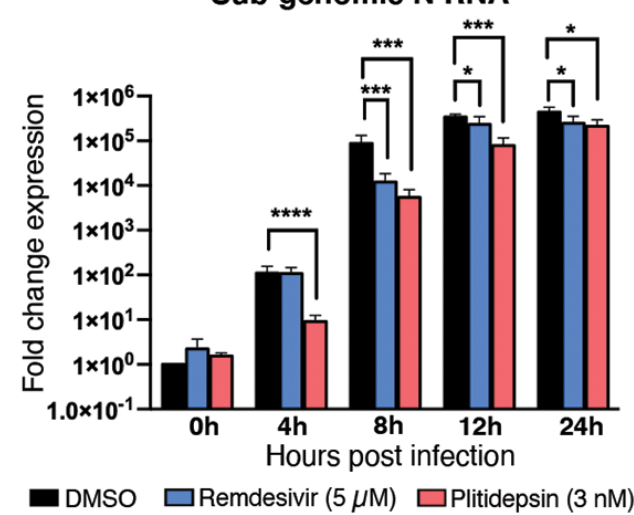

C

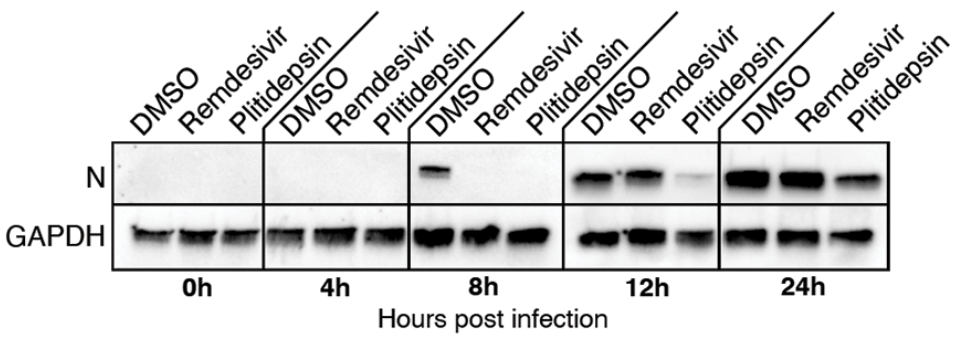

Concentrations: $5 \mu \mathrm{M}$ Remdesivir \& $3 \mathrm{nM}$ Plitidepsin

D

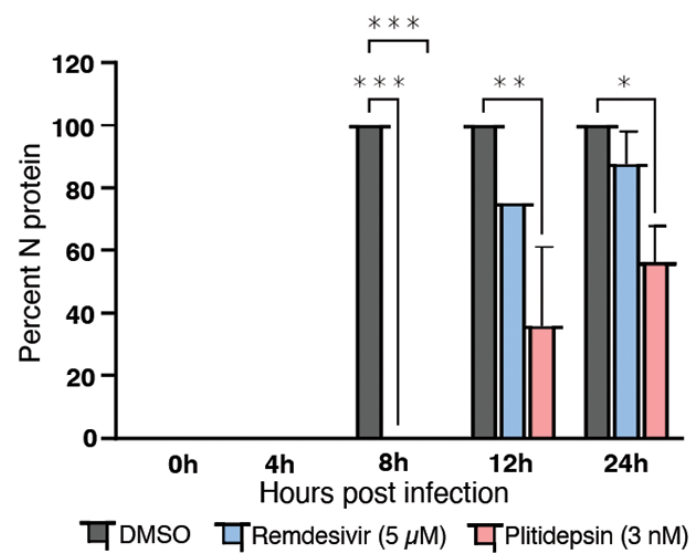

Fig. 3. Plitidepsin treatment causes a specific reduction in sub-genomic RNA expression. (A to D) Vero E6 cells were infected with the SARS-CoV-2 at an MOI of 1 in the presence or absence of $3 \mathrm{nM}$ plitidepsin or $5 \mu \mathrm{M}$ remdesivir and samples were taken at the indicated time points. The levels of genomic RNA (A) and subgenomic N RNA (B) were analyzed with specific reverse transcription quantitative polymerase chain reactions (RT-qPCR). (C) Cell lysates were collected at indicated times and subjected to Western blotting analysis. (D) Each protein band was quantified by ImageJ and normalized to GAPDH levels. Means \pm SD (error bars) of three independent experiments performed in biological triplicate are indicated ${ }^{*} \mathrm{P}<0.05$, ${ }^{*} \mathrm{P}<0.01$, ${ }^{* *} \mathrm{P}<0.001$, and $\left.{ }^{* * *} P<0.0001\right)$. 

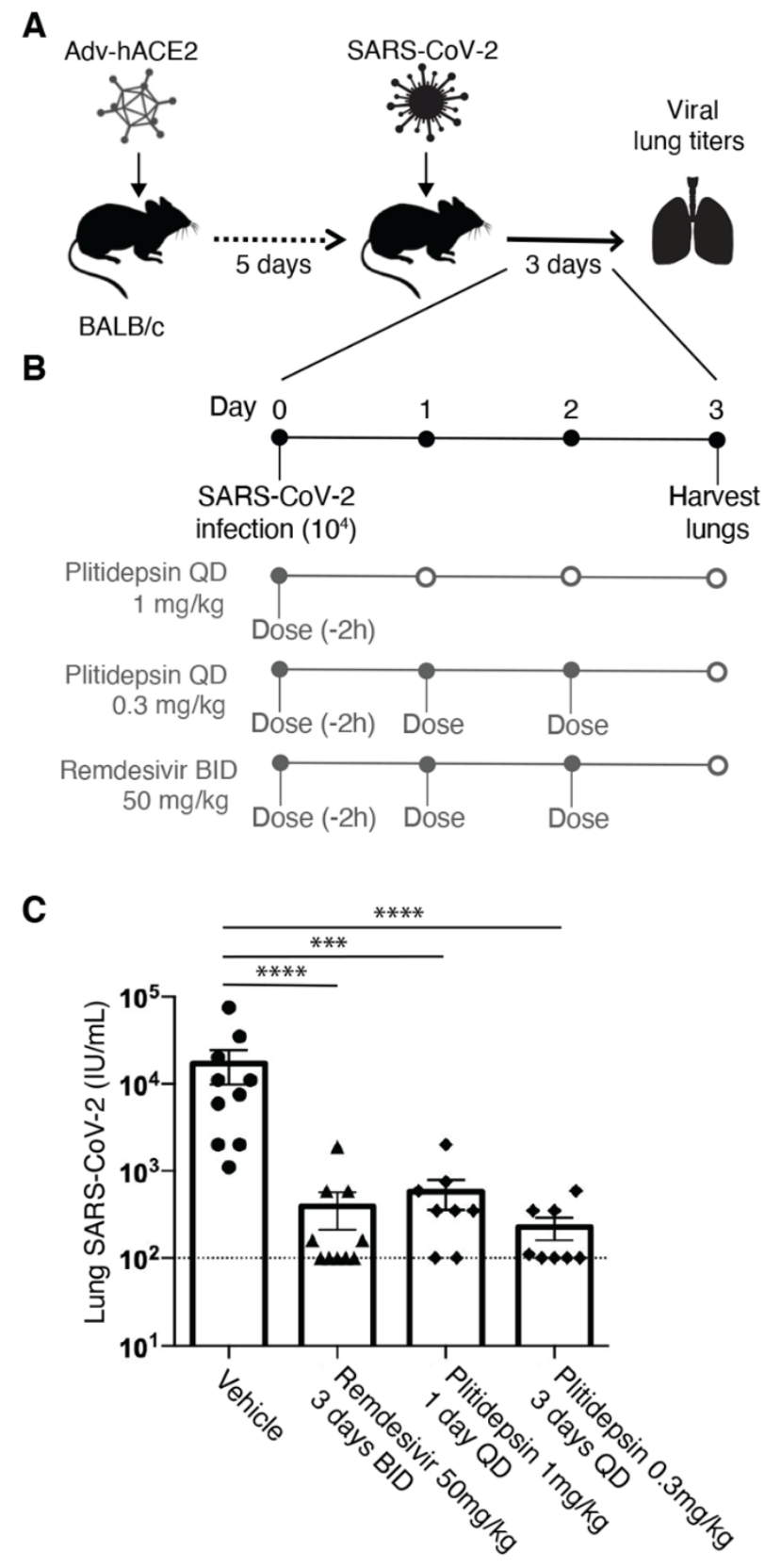

Fig. 4. Plitidepsin treatment significantly reduces SARS-CoV-2 infection in BALB/c mice expressing human ACE2. (A) Schematic of adenovirus expression of human ACE2 model of SARS-CoV-2 infection. $\mathrm{BALB} / \mathrm{c}$ mice were transduced with human ACE2 expressing adenovirus (Mice were sensitized intranasally with $2.5 \times 108$ PFU). (B) Mice were intranasally infected with 104 PFU of SARS-CoV-2 and subcutaneously treated with $0.3 \mathrm{mg} / \mathrm{kg}$ plitidepsin once daily for 3 days, a single dose of $1 \mathrm{mg} / \mathrm{kg}$ plitidepsin, or with $50 \mathrm{mg} / \mathrm{kg}$ remdesivir once daily for 3 days. (C) SARS-CoV-2 lung titers in the plitidepsin treated group relative to vehicle and remdesivir controls. Virus titers were determined in whole lung homogenates by TCID50 at day 3 post-infection. The limit of detection for viral titers is indicated with a dotted line. Vehicle and remdesivir $\mathrm{N}=10$, plitidepsin $1 \mathrm{mg} / \mathrm{kg}$ and $0.3 \mathrm{mg} / \mathrm{kg} \mathrm{N}=8\left({ }^{*} \mathrm{P}\right.$ $<0.05$, ${ }^{*} \mathrm{P}<0.01$, ${ }^{* *} \mathrm{P}<0.001$, and ${ }^{*}{ }^{*} \mathrm{*} P<0.0001$ ). 
A
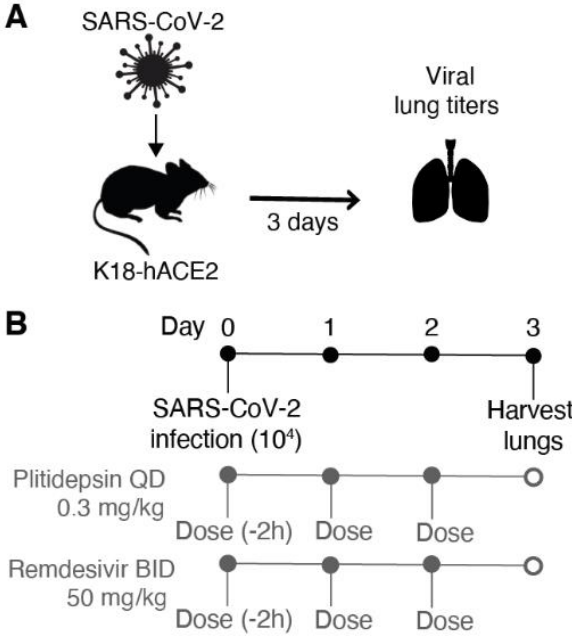

C

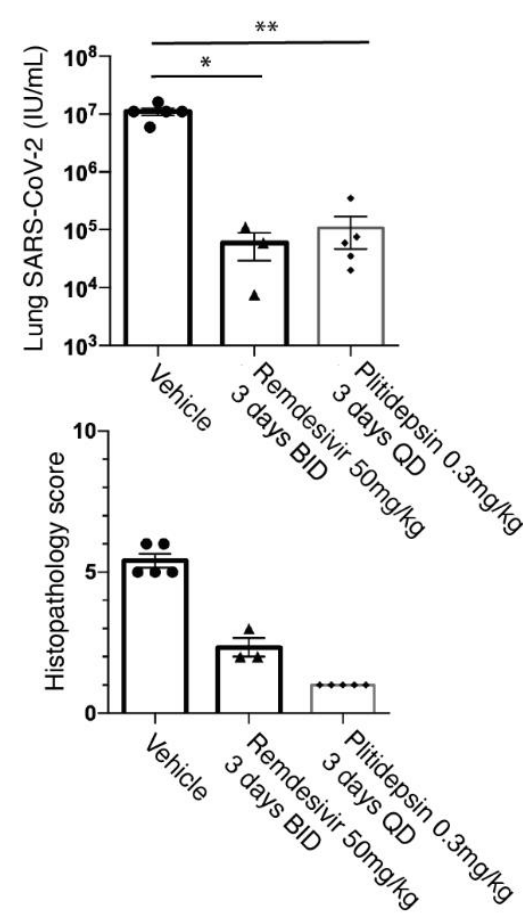

D

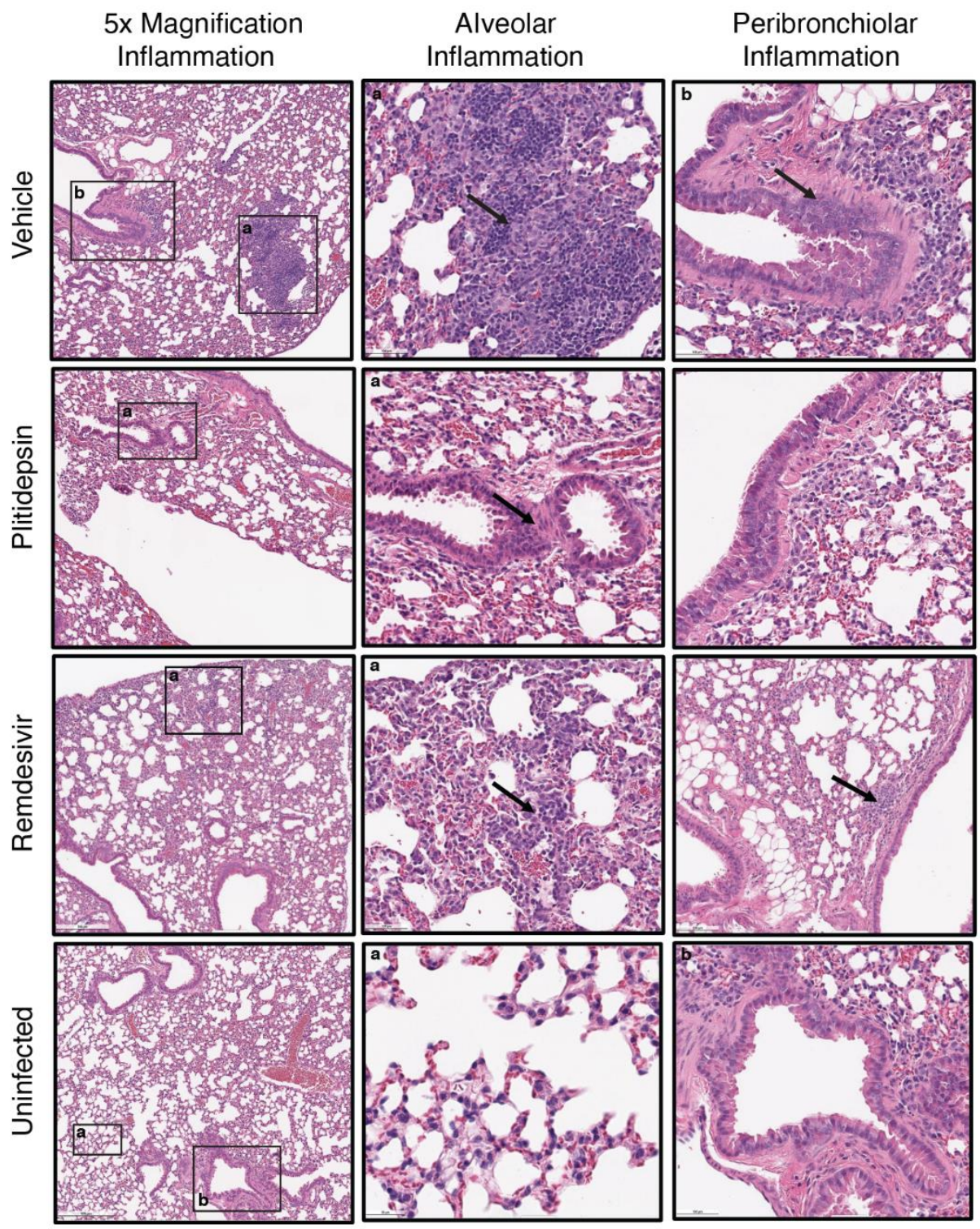

Fig. 5. Plitidepsin shows in vivo antiviral efficacy in the K18-hACE2 mouse model. (A) Schematic of the K18-hACE2 model of SARS-CoV-2 infection. (B) Mice were intranasally infected with 104 PFU of SARS-CoV-2 and subcutaneously treated with $0.3 \mathrm{mg} / \mathrm{kg}$ plitidepsin once daily for 3 days or with $50 \mathrm{mg} / \mathrm{kg}$ remdesivir twice daily for 3 days. (C) SARSCoV-2 lung titers in the plitidepsin treated group relative to vehicle and remdesivir controls. Virus titers were determined in whole lung homogenates by TCID50 at day 3 post-infection. Five mice were used in each group, except for the remdesivir control which had $3\left({ }^{*} \mathrm{P}<0.05\right.$, ${ }^{* *} \mathrm{P}<0.01$, ${ }^{* * *} \mathrm{P}<0.001$, and $\left.{ }^{* * * * P}<0.0001\right)$. (D) Lungs were harvested on day 3 post-infection, paraffin embedded and $5 \mu \mathrm{m}$ sections stained for H\&E. Regions of the lung anatomy where inflammation was assessed are highlighted by black boxes. Regions were inflammation was detected are indicated by arrows. (E) Pathological severity scores in infected mice. To evaluate comprehensive histological changes, lung tissue sections were scored based on pathological changes outlined in the supplementary materials. 